\title{
CHARACTERIZATION OF PACIFIC SILVER FIR IMPREGNATED WITH EXTRACTIVES FROM WESTERN REDCEDAR
}

\author{
Rod Stirling ${ }^{1, \AA}$ Stacey Kus $^{2}$
}

\begin{abstract}
Alternative and higher value uses are needed for residual materials generated from wood products processing. Western redcedar sawdust contains an array of unique chemicals and has the potential to be used to alter the appearance, stability and durability of non-durable timbers. Here it was hypothesized that impregnation of Western redcedar heartwood extractives into Pacific silver fir would decrease shrinkage, hygroscopicity, and susceptibility to decay. Western redcedar hot water extracts were obtained from sawdust and used to pressure-treat Pacific silver fir blocks. Extractive impregnation enhanced the wood's appearance and gave it a more cedar-like brown colour. Impregnated samples had reduced shrinkage, but were not as dimensionally stable as Western redcedar heartwood. Pacific silver fir blocks impregnated with water-soluble extractives were also highly susceptible to leaching, and leached samples had similar shrinkage values to untreated controls. In contrast, leaching had little effect on the hygroscopicity of the Western redcedar heartwood. Extractive-impregnated Pacific silver fir blocks had increased resistance to decay by two brown-rot fungi, and showed resistance similar to that of Western redcedar heartwood. However, leached blocks did not have the same decay resistance.
\end{abstract}

Keywords: Dimensional stability, durability, extractives, impregnation, western redcedar.

\section{INTRODUCTION}

Western redcedar (Thuja plicata) (WRC) heartwood is well known for its natural resistance to decay, its dimensional stability, and its low hygroscopicity (Gonzalez 2004). The extractives associated with these properties are present in residual products (e.g. sawdust and planer shavings) from wood products processing. Because of the unique compounds found in WRC, it may be possible to derive greater value from sawdust than burning it for energy. Several companies have investigated, and continue to investigate, ways of extracting and marketing these products. One of the simplest uses would be to use the crude extract as a treatment for other wood products. Pacific silver fir (Abies amabilis) (PSF) would be the ideal substrate as it is often processed along with WRC, and is moderately treatable (Morris 1995), but lacks the dimensional stability and decay resistance that extractives provide in WRC heartwood (Glass and Zelinka 2010).

Several researchers have investigated the possibility of removing extractives from durable species and impregnating them into sapwood, or non-durable heartwoods from other species (Southam and Ehrlich 1943, Anderson et al. 1958, Rudman 1962, Yamamoto and Hong 1988, Hart 1989, Turner and Conradie 1995, Diouf et al. 2002, Clausen and Yang 2007, Li et al. 2012, Kirker et al. 2013, Silviera et al. 2017). This approach has met with mixed results; the durability of extractive-impregnated wood was usually equal to or lower than that of the heartwood from which the compounds were sourced. Extractives with fungitoxic activity that can be fully extracted tend to have similar activity in other woods. However, extractives that contribute to durability via mechanisms other than fungitoxicity are often less effective because their efficacy is related to their location within the wood cell and this cannot be easily replicated by impregnation processes. The intracellular distribution of extractives may affect decay resistance, though there are few studies examining this (Taylor $e t$ al. 2002). WRC extractives are been detected within tracheid walls (Shi and Avramidis 2018) and it has been 
hypothesized that the presence of these compounds in the tracheid wall may contribute to the wood's hygroscopic and fungal resistance properties (Stirling and Morris 2016).

Dimensional stabilization technologies rely on bulking or crosslinking of the wood cell wall. The use of extractives for dimensional stabilization has been investigated. Sakai et al. (1999) examined Sitka spruce impregnated with various extractive compounds and found anti-shrink efficiencies up to $40 \%$ for samples treated with a $10 \%$ weight percent gain (WPG) with heavily hydroxylated extractives, including catechin. Simple phenolics and oligomeric material did not have this effect. In related work, Ermeydan et al. (2012) reacted tosylated flavonoids with Norway spruce wood cell walls to improve dimensional stability. While WRC extractives have been associated with the dimensional stability of WRC heartwood, they have not been assessed for their ability to impart dimensional stability in other woods. WRC lignans are heavily hydroxylated and are known to condense to form oligomeric compounds (Kai and Swan 1990, Johansson et al. 2000). These compounds have been detected in the cell wall of WRC heartwood and found to affect the physical properties of the wood (Yano 1994, Stirling and Morris 2006). It is hypothesized that these compounds will react with hem-fir cell walls under warm, wet conditions resulting in wood that will have enhanced dimensional stability and reduced hygroscopicity, as is observed in WRC heartwood.

Most of the research on extractive impregnation has focused on improving decay and/or termite resistance. Little is known about how extractive impregnations may impact other wood properties, such as hygroscopicity and dimensional stability. Reduced hygroscopicity and increased dimensional stability have been associated with the presence of extractives in WRC heartwood (Wangaard and Granados 1967, Stirling and Morris 2006). We therefore hypothesize that impregnation of these compounds into the more hygroscopic and less dimensionally stable PSF will reduce hygroscopicity, increase dimensional stability, and improve decay resistance.

\section{MATERIALS AND METHODS}

\section{Preparation of test materials}

WRC sawdust (approximately $20 \mathrm{~kg}$ ) was obtained from a cedar sawmill in coastal British Columbia. The mill is a secondary manufacturer of WRC and as such produces relatively dry, clean sawdust with very little bark or dirt. Water extraction was selected because it has a low cost and does not require expensive solvent handling equipment. From this sample, five subsamples, approximately $20 \mathrm{~g}$ each, were taken for moisture content determination by oven drying. Average moisture content was $26 \%$ (standard deviation $8 \%$ ). Approximately $5,5 \mathrm{~kg}$ of sawdust (OD equivalent) was refluxed in distilled water for 3 hours, cooled, and passed through a Buchner filter to remove particulate. Extracts were then reduced by rotary evaporation and freeze dried. Extracts were prepared in seven batches with an average yield of $4,3 \%$ of sawdust mass (standard deviation $0,7 \%$ ). Approximately $240 \mathrm{~g}$ of extract was obtained in total. Sawdust samples were analyzed for extractives following the methods outlined by Daniels and Russell (2007) (Table 1).

Table 1: Extract yield and composition.

\begin{tabular}{ccc}
\hline Extractive & $\begin{array}{c}\text { Concentration in Sawdust } \\
\text { (ppm) }\end{array}$ & $\begin{array}{c}\text { Concentration in Extract } \\
\text { (ppm) }\end{array}$ \\
\hline Plicatic acid & 9583 & 550921 \\
Thujaplicins & 1929 & 246 \\
Thujic acid & 1104 & 366 \\
\hline
\end{tabular}

Kiln-dried PSF sapwood and WRC heartwood were sourced from a mill in coastal British Columbia. One hundred and twenty-five blocks each measuring 6 (t) x 25 (r) x 25 (l) mm were cut for dimensional stability testing. Four hundred blocks measuring 6 (t) x 15 (r) x 25 (l) mm were cut for decay testing. The experiment groups are summarized in Table 2. 
Extracts were reconstituted in hot distilled water and pressure impregnated into the PSF samples using a full cell process, which included a 30 min initial vacuum at $-94 \mathrm{kPa}$, followed by a $1 \mathrm{~h}$ press at $414 \mathrm{kPa}$. Samples were either dried at $70^{\circ} \mathrm{C}$ following treatment, or conditioned wet at $60^{\circ} \mathrm{C}$ for 37 days and then dried at $70^{\circ} \mathrm{C}$. The wet conditioning was intended to allow further migration and redistribution of active ingredients in the cell walls. Red pine (Pinus resinosa) sapwood samples were included in decay testing as negative controls to assess fungal vigor. WRC heartwood samples were also included in this study as positive controls.

Table 2: Experiment summary.

\begin{tabular}{|c|c|c|c|c|c|c|}
\hline Group & Species & $\begin{array}{l}\text { Impregnation } \\
\text { Target }\end{array}$ & Conditioning & $\begin{array}{c}\text { Physical } \\
\text { Testing }\end{array}$ & $\begin{array}{l}\text { Decay } \\
\text { Testing }\end{array}$ & $\begin{array}{l}\text { Average } \\
\text { Weight } \\
\text { Percent } \\
\text { Gain } \\
(\%)^{* *}\end{array}$ \\
\hline 1 & WRC & Water & Dry at $70^{\circ} \mathrm{C}$ & $\mathrm{X}$ & $\mathrm{X}$ & N/A \\
\hline 2 & WRC & Water & $\begin{array}{c}37 \text { days wet at } 60^{\circ} \mathrm{C}, \\
\text { dry at } 70^{\circ} \mathrm{C}\end{array}$ & $\mathrm{X}$ & $\mathrm{X}^{*}$ & N/A \\
\hline 3 & PSF & Water & Dry at $70^{\circ} \mathrm{C}$ & $\mathrm{X}$ & $\mathrm{X}$ & N/A \\
\hline 4 & PSF & Water & $\begin{array}{c}37 \text { days wet at } 60^{\circ} \mathrm{C}, \\
\text { dry at } 70^{\circ} \mathrm{C}\end{array}$ & $\mathrm{X}$ & $X^{*}$ & N/A \\
\hline 5 & PSF & $\begin{array}{c}\text { Raw extract } 10 \% \\
\text { WPG }\end{array}$ & Dry at $70^{\circ} \mathrm{C}$ & $\mathrm{X}$ & $\mathrm{X}$ & $\begin{array}{l}11.4 \\
(0,4)\end{array}$ \\
\hline 6 & PSF & $\begin{array}{l}\text { Raw extract } 10 \% \\
\text { WPG }\end{array}$ & $\begin{array}{c}37 \text { days wet at } 60^{\circ} \mathrm{C}, \\
\text { dry at } 70^{\circ} \mathrm{C}\end{array}$ & $\mathrm{X}$ & $\mathrm{X}$ & $\begin{array}{l}11,5 \\
(0,2)\end{array}$ \\
\hline 7 & PSF & $\begin{array}{c}\text { Raw extract } 20 \% \\
\text { WPG }\end{array}$ & Dry at $70^{\circ} \mathrm{C}$ & $\mathrm{X}$ & $\mathrm{X}$ & $\begin{array}{l}19,2 \\
(0,6)\end{array}$ \\
\hline 8 & PSF & $\begin{array}{c}\text { Raw extract } 20 \% \\
\text { WPG }\end{array}$ & $\begin{array}{c}37 \text { days wet at } 60^{\circ} \mathrm{C}, \\
\text { dry at } 70^{\circ} \mathrm{C}\end{array}$ & $\mathrm{X}$ & $\mathrm{X}$ & $\begin{array}{l}19,0 \\
(0,9)\end{array}$ \\
\hline 9 & Red pine & N/A & N/A & & $\mathrm{X}$ & N/A \\
\hline 10 & WRC & N/A & N/A & & $X$ & N/A \\
\hline
\end{tabular}

Physical tests were conducted on 10 specimen blocks selected from each of the treatment groups listed in Table 2. After these tests were complete, the blocks were leached based on AWPA E11-16 (2016) with modifications. Three additional blocks were included in each leachate group increasing the number leached to nine. Nine blocks from each treatment group used for physical property assessment were impregnated with distilled water in a pressure vessel and placed into beakers with $250 \mathrm{~mL}$ of distilled water. Water was changed after 6 , $24,48,101,169,217,268,316$ and 364 hours. Some leachate fractions were analyzed for WRC extractives by HPLC, and blocks were re-conditioned and weighed to determine mass loss. Dimensional stability, hygroscopicity and colour were reassessed on leached blocks using the methods described below.

\section{Physical properties assessments}

One block from each treatment group prior to leaching was used for microscopic analysis to confirm that extractives were deposited within the wood. Small cut sections were imaged, uncoated, at $15 \mathrm{kV}$ and 1 Torr pressure in a FEI Quanta 400F Environmental Scanning Electron Microscope (ESEM). Areas of similar morphology on the radial faces of the sections were selected for imaging.

Percent shrinkage was calculated in the tangential and radial directions as the ratio of the change in dimension to the wet state dimension. Nine test blocks, previously conditioned to dryness at $40^{\circ} \mathrm{C}$ and $0 \% \mathrm{RH}$, were carefully wetted with distilled water and exposed in an environment chamber $20^{\circ} \mathrm{C}$ and $95 \% \mathrm{RH}$ until they reached a constant weight. Each block was then weighed, and tangential and radial dimensions measured with a digital caliper. All blocks were then oven dried, re-weighed, and re-measured. Moisture content was calculated to show that all samples were indeed above the fiber saturation point when in the wet state. 
Dry blocks were exposed to $30^{\circ} \mathrm{C}$ and $90 \%$ relative humidity for one week in an environment chamber. Moisture content was determined gravimetrically to assess the relative hygroscopicity of the materials.

Quantitative colour measurements were made using a Konica Minolta CM-700d spectrophotometer. L* defines lightness, with 0 being black and 100 being white. $a^{*}$ defines green/red colour space, where green values are negative and red values are positive. $b^{*}$ defines blue/yellow colour space, where blue values are negative and yellow values positive.

\section{Decay resistance assessments}

The test method followed the AWPA E10-16 (2016). All PSF blocks were initially Soxhlet extracted with water and dried prior to obtaining initial weights to reduce the risk of water soluble nutrients affecting the growth of the decay fungi. Forty-eight test blocks were prepared for each treatment group. The blocks were then randomly divided into the two conditioning groups, the first group conditioned wet for 37 days at $60^{\circ} \mathrm{C}$ then dried at $70^{\circ} \mathrm{C}$ for $24 \mathrm{~h}$ and the second group dried at $70^{\circ} \mathrm{C}$ for $24 \mathrm{~h}$ right after treatment. The twenty blocks that had solution uptakes closest to the target were selected for testing in an eight week soil block test. Conditioned weights were obtained after 24 hours in a $70^{\circ} \mathrm{C}$ oven. Blocks were then packaged for sterilization and irradiated with two passes at $17 \mathrm{kGy}$ by Iotron industries. Nine were exposed to Gloeophyllum trabeum Ftk 47D and nine to Rhodonia placenta Ftk 120F. Two blocks were placed in soil jars without added inoculum as check block controls. All control sample sets contained ten replicate blocks exposed to each fungi and two uninoculated check blocks.

Soil moisture content was adjusted to approximately 50\% moisture content and tamped down to form a level sample surface. Two red pine sapwood feeder strips were then placed side by side on top of the soil and a lid affixed. Each jar was then sterilized by autoclaving at $120^{\circ} \mathrm{C}$ and $103,4 \mathrm{kPa}$ for one hour. After cooling under sterile conditions, the jars were inoculated with either G. trabeum or R. placenta or left uninoculated. After three weeks of incubation at $25^{\circ} \mathrm{C}$ and $85 \%$ relative humidity, good mycelial growth was observed on the feeder strips and the irradiated blocks were placed atop the inoculated feeder strips ensuring end-grain contact with growing/active mycelia. Only blocks from the same treatments group were placed within a single jar to prevent sample treatment influence. The jars were then incubated for a further 8 weeks. Blocks were then removed from the jars and reconditioned for $24 \mathrm{~h}$ in a $70^{\circ} \mathrm{C}$ oven and reweighed.

Leached blocks were assessed in a separate soil block decay test and were only exposed to $R$. placenta Ftk $120 \mathrm{~F}$. Due to the limited number of samples available only one test set was possible and therefore $R$. placenta was chosen as it had higher rates of decay in the initial decay test. The same procedures were followed with the following differences: only eight test blocks and one check block for each group was included in the soil jar test due to sample number limitations. Leached blocks were larger in size, 6 × 25 x $25 \mathrm{~mm}$, than the original soil jar test samples and therefore required an eleven week exposure time.

\section{RESULTS AND DISCUSSION}

\section{Physical properties}

Scanning electron micrographs confirmed the presence of globular deposits assumed to be extractives in the lumen and around the pits in PSF wood impregnated with WRC extracts (Figure 1). Cell wall penetration was not assessed. 


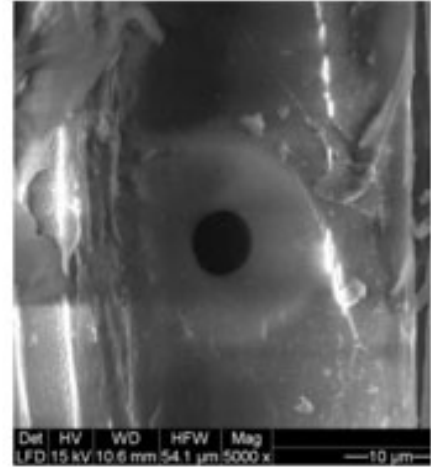

(a)

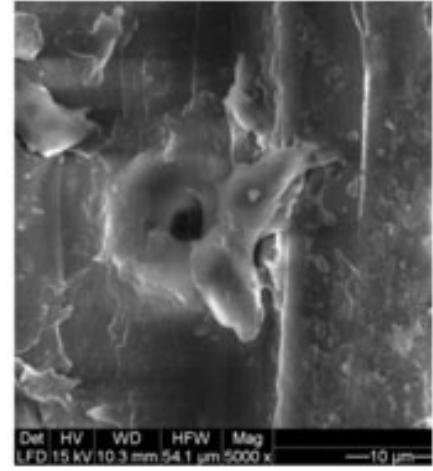

(b)

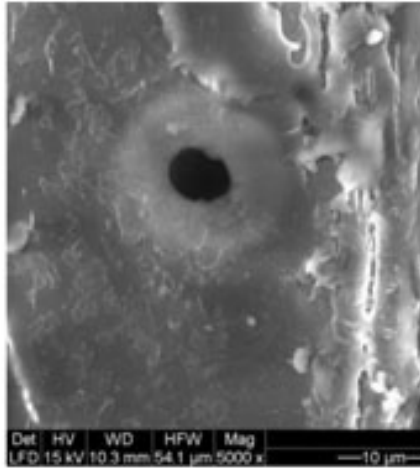

(c)

Figure 1: Environmental scanning electron micrograph of a tracheid and pit in (a) Pacific silver fir - untreated, (b) impregnated with $20 \%$ raw extract, and (c) impregnated with $20 \%$ raw extract and conditioned.

The mass losses from each treatment group following the laboratory leaching procedure are shown in Figure 2. Large quantities of impregnated extractives were leached out of the impregnated blocks at both $10 \%$ and 20\% WPG, regardless of post-conditioning method. However, post-conditioned materials did leach less than equivalent unconditioned materials. The post-conditioning treatment is still highly susceptible to leaching and therefore likely not suitable for use preparing wood for exterior applications where leaching would occur.

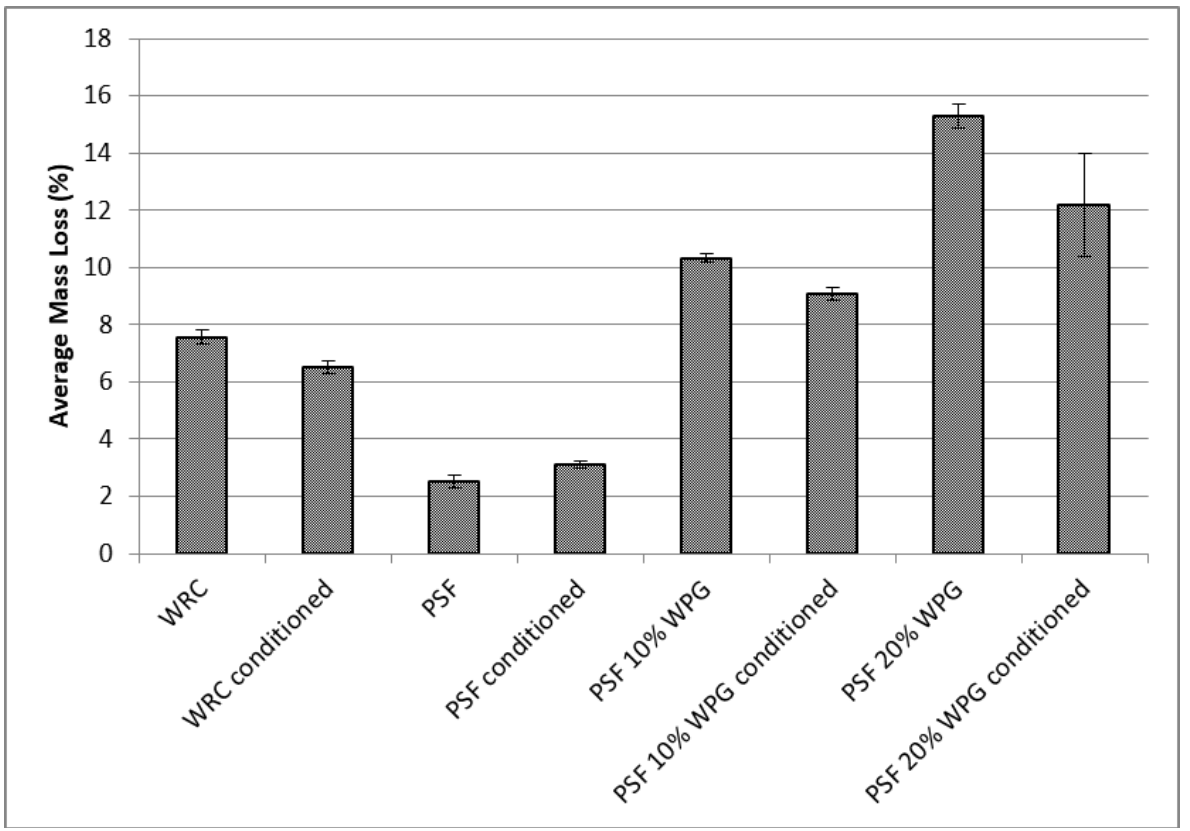

Figure 2: Average Mass Loss of Extractive-Impregnated Pacific Silver Fir after Leaching (Error bars represent standard deviations).

Leachates taken from the first 3 cycles were analyzed for extractives to confirm that mass losses were attributable to loss of WRC extractives. Plicatic acid was present in the WRC heartwood leachates and in impregnated PSF leachates (Table 3). Concentration in the WRC heartwood leachates was similar at each sampling time. Concentration in the leachates from extractive-impregnated blocks was initially much higher than in the WRC heartwood leachates, but decreased substantially in later sampling events. Conditioning did not have a major impact on plicatic acid concentration in the leachates. Concentrations of thujic acid and the thujaplicins were only present in very low quantities and are not reported here. 
Table 3: Concentration of Plicatic Acid in Leachates.

\begin{tabular}{clccc}
\hline \multirow{2}{*}{ Group } & \multirow{2}{*}{ Description } & \multicolumn{3}{c}{ Plicatic acid $(\boldsymbol{\mu g} / \mathbf{m L})$} \\
\cline { 3 - 5 } & WRC, dry & $\mathbf{6} \mathbf{h}$ & $\mathbf{2 4} \mathbf{h}$ & $\mathbf{4 8} \mathbf{~ h}$ \\
\hline 2 & WRC, conditioned & 38 & 29 & 29 \\
\hline 3 & PSF, dry & N/A & 24 & 34 \\
\hline 4 & PSF, conditioned & N/A & N/A & N/A \\
\hline 5 & PSF, raw extract 10\% WPC, dry & 166 & 133 & 58 \\
\hline 6 & $\begin{array}{l}\text { PSF, raw extract 10\% WPC, } \\
\text { conditioned }\end{array}$ & 140 & 62 & 82 \\
\hline 7 & PSF, raw extract 20\% WPC, dry & 226 & 79 & 110 \\
\hline 8 & $\begin{array}{l}\text { PSF, raw extract 20\% WPC, } \\
\text { conditioned }\end{array}$ & 225 & 204 & 75 \\
\hline
\end{tabular}

Percent shrinkage values, before and after leaching, are reported in Figure 3 and Figure 4. Post-conditioning did not affect WRC heartwood shrinkage. Radial shrinkage values were similar to the literature value of $2,4 \%$ while tangential shrinkage values were slightly lower than the literature value of 5,0\% reported by Glass and Zelinka (2010). PSF shrinkage values were higher than the literature values of 4,4\% (radial) and 9,2\% (tangential) of Glass and Zelinka (2010). Impregnation with WRC extractives to a 10\% WPG significantly reduced radial shrinkage by 18 to $21 \%$ and tangential shrinkage by 9 to $14 \%$ prior to leaching. Impregnation with WRC extractives to a $20 \%$ WPG significantly reduced radial shrinkage by 24 to $34 \%$ and tangential shrinkage by 18 to $28 \%$ prior to leaching. Despite these gains, even the most dimensionally stable treated PSF blocks showed nearly twice the shrinkage of WRC heartwood. Moreover, after leaching, the shrinkage of extract-impregnated samples increased to levels similar to unimpregnated controls. The results indicate that the extract impregnation methods used in this study would not enhance dimensional stability of the wood if exposed to exterior conditions where leaching would occur.

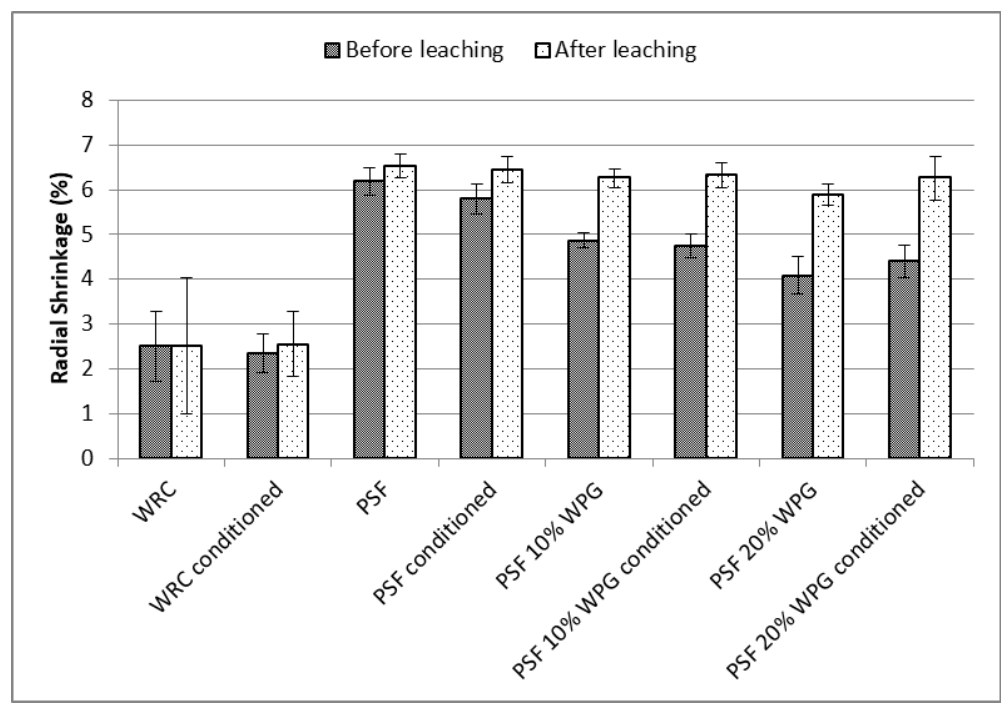

Figure 3: Radial shrinkage of Pacific silver fir impregnated with western redcedar extractives before and after leaching (Error bars represent standard deviations). 


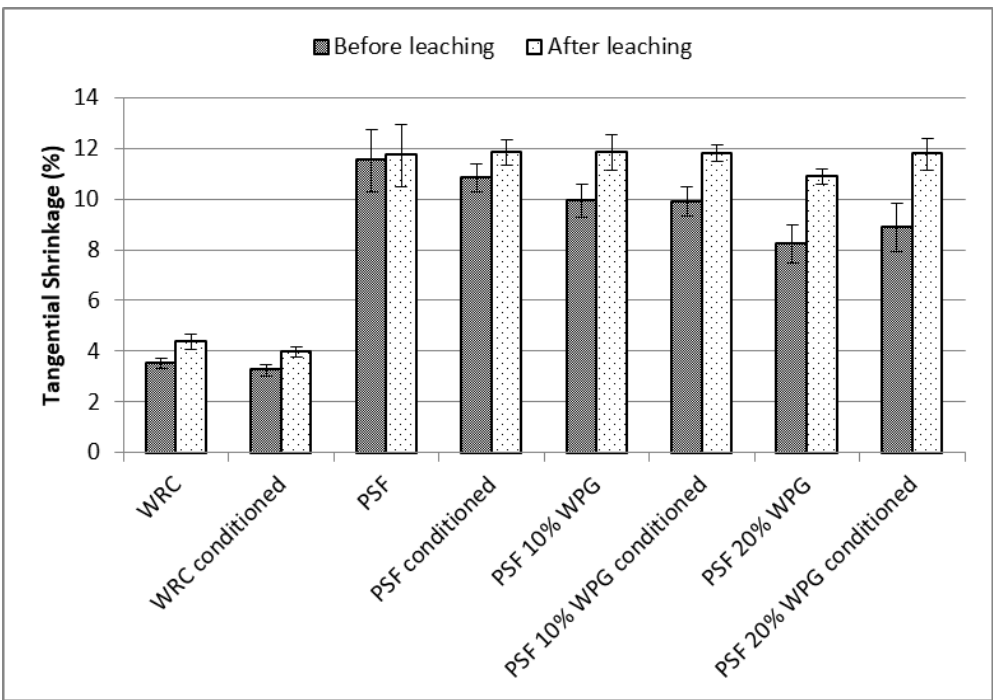

Figure 4: Tangential shrinkage of Pacific silver fir impregnated with western redcedar extractives before and after leaching (Error bars represent standard deviations).

Moisture content following one week of conditioning at high humidity resulted in a moisture content of approximately $20 \%$ in PSF controls (Figure 5). Impregnation with WRC was associated with a small reduction in moisture content to approximately $18 \%$. However, this was not as low as the moisture content of $16-17 \%$ observed in the WRC reference. After leaching, the moisture content of the WRC heartwood reference increased. This is consistent with previous work on this topic (Stirling and Morris 2006). Moisture content in extractive-impregnated PSF blocks was similar before and after leaching. This suggests that residual extractives were present at least partially within the cell wall where they would affect hygroscopic properties. After leaching and conditioning at high humidity, the PSF samples impregnated with extractives to a $20 \%$ weight gain and the WRC heartwood controls reached a similar moisture content.

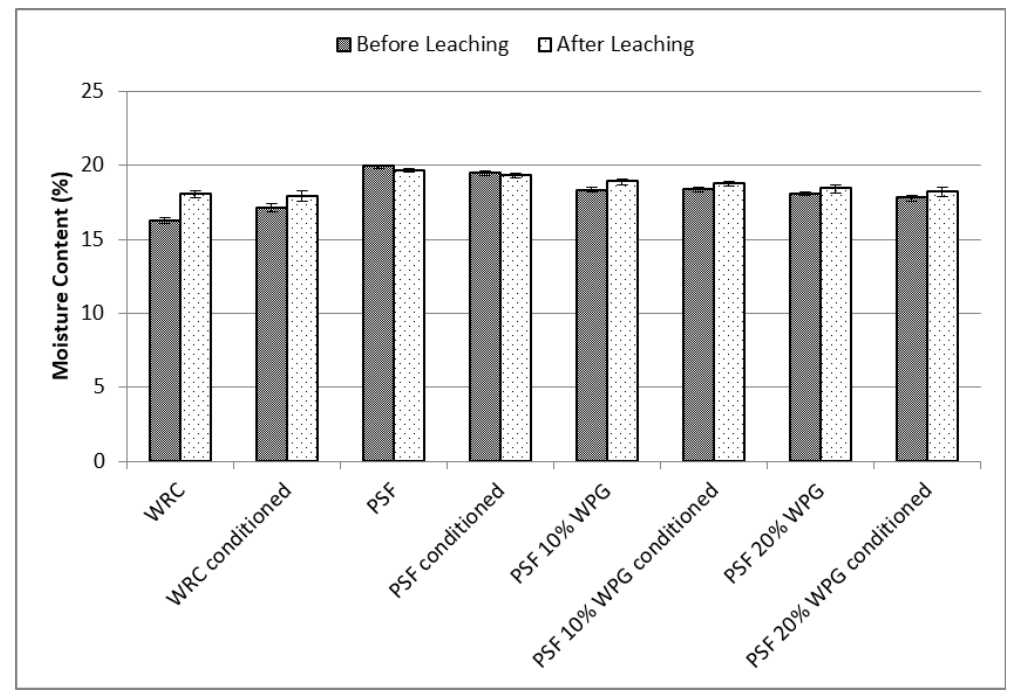

Figure 5: Average Moisture Content after conditioning at $90 \%$ relative humidity and $30^{\circ} \mathrm{C}$ for 1 week for western redcedar and Pacific silver fir impregnated with WRC extractives before and after leaching (Error bars represent standard deviations). 
Wood colour was measured before and after leaching (Figure 6, Figure 7 and Figure 8). Extractive impregnation was associated with PSF sapwood becoming darker, less red, and more yellow. In addition, the conditioning step was associated with darkening in all blocks, and reduced yellowing in extractive impregnated blocks. Conditioned blocks had similar colour before and after leaching, while unconditioned, impregnated blocks became lighter, less red, and less yellow. Extractive impregnation was an effective way to give PSF a similar colour to WRC heartwood.

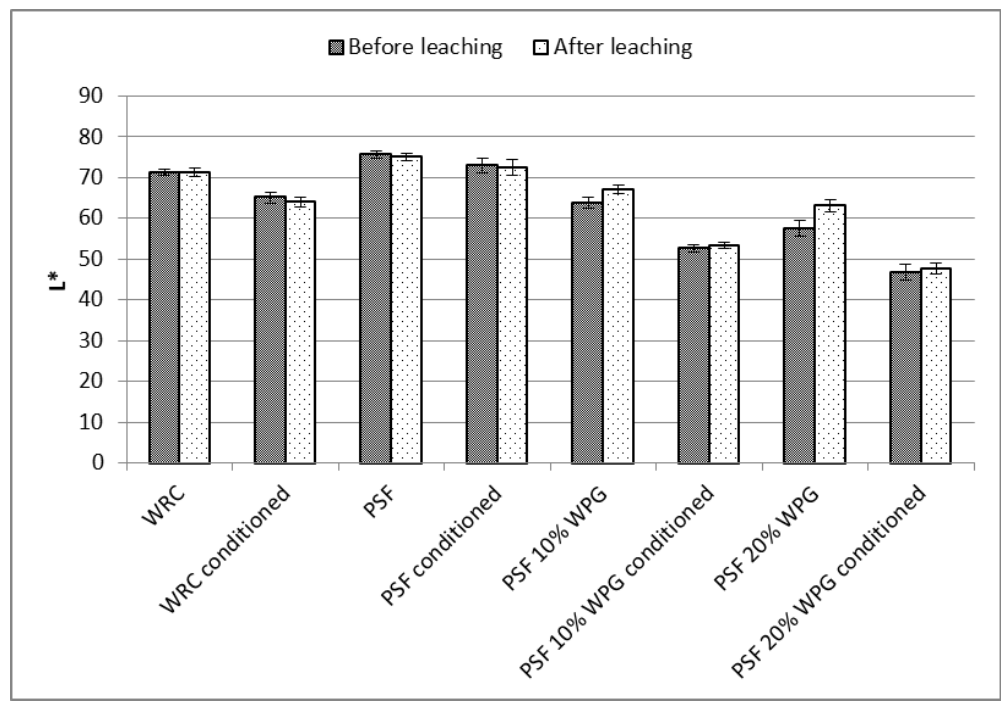

Figure 6: Average L* (lightness) values for Western redcedar and Pacific silver fir impregnated with western redcedar extractives before and after leaching. Error bars represent standard deviations.

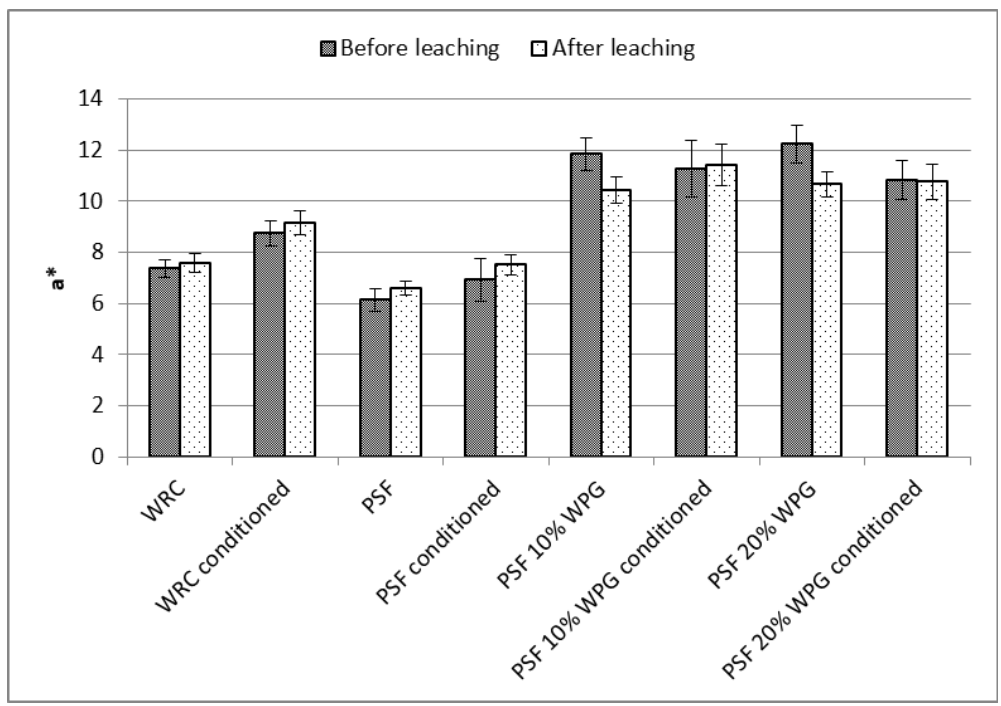

Figure 7: Average a* (green-red) values for Western redcedar and Pacific silver fir impregnated with western redcedar extractives before and after leaching. Error bars represent standard deviations. 


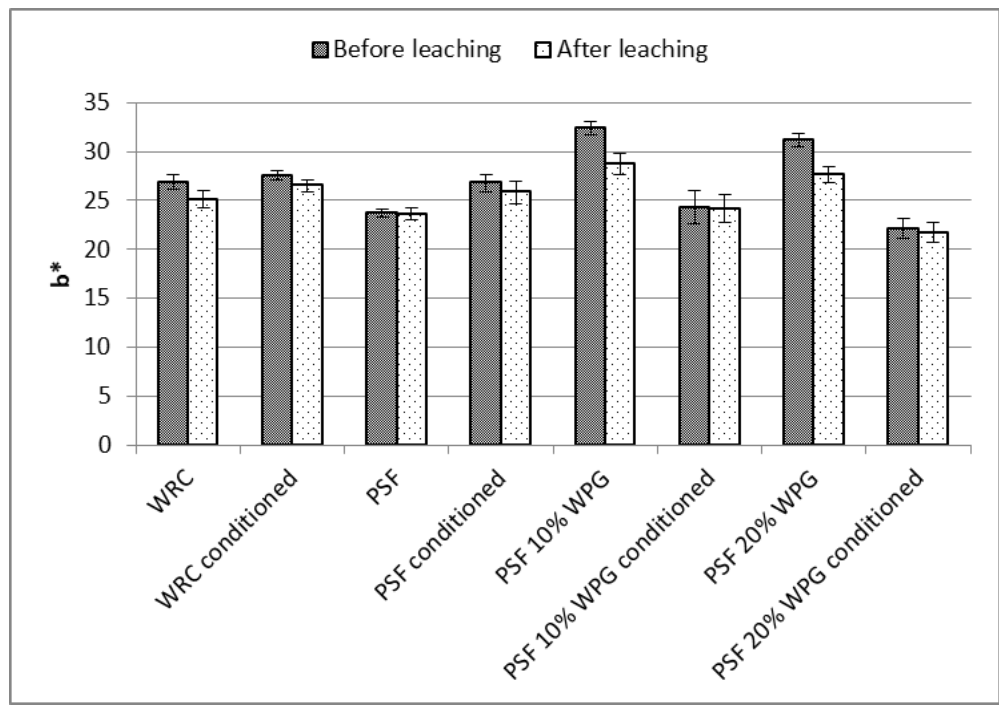

Figure 8: Average b* (blue-yellow) values for Western redcedar and Pacific silver fir impregnated with western redcedar extractives before and after leaching. Error bars represent standard deviations.

\section{Decay resistance}

Block moisture contents and weight losses were calculated based on the difference between post-treatment conditioned weight and post-incubation conditioned weight. Weight losses were adjusted further using the non-inoculated check block results to compensate for any non-fungal weight loss or gains during incubation.

Moisture content was determined for each block and averaged by group. High moisture content (above $25 \%$ ) confirms conditions were suitable for decay and that the test was viable. Weight loss data was also collected for each block and averaged by sample group. Table 4 contains the average moisture content data as well as the average corrected weight loss data for both leached and non-leached soil block tests.

Unleached PSF blocks treated with WRC extractives had average corrected weight loss values less than $3 \%$, similar to the WRC heartwood. After leaching average corrected weight loss values increased significantly to $47,6-57,2 \%$ which was higher that the negative controls. A low weight loss $(3,0 \%)$ was observed in the leached samples dried at $70^{\circ} \mathrm{C}$, which is consistent with previous findings with this fungus (Stirling et al. 2017). However, a higher weight loss $(32,7 \%)$ was observed in the leached samples conditioned wet at $60^{\circ} \mathrm{C}$ prior to drying. The reasons for the discrepancy are unclear. There may have been some loss of volatile extractives during the extended exposure time, or the prolonged damp exposure may have increased extractive solubilization. MacDonald and MacLean (1965) found that some thujaplicins were lost during high temperature kiln drying. However, they concluded the results were negligible. The extended period at elevated temperature used in this experiment may have contributed to greater losses of these compounds. The negative control samples, the untreated red pine sapwood and the water-extracted PSF sapwood blocks, all had significant decay losses (48,3-51,9\% and 30,8-53,7\% respectively). No effect of weight percent gain or post conditioning on weight loss was observed in the unleached soil block test as there was little weight loss in any of the treated samples. The low weight losses observed in the unleached samples is likely due largely to the presence of thujaplicin in the raw extract. Thujaplicins, even at low concentrations, have been shown to be effective against brownrot fungi (Li et al. 2012), while purified lignans have been shown to be ineffective at controlling these fungi (Stirling and Morris 2016). 
Table 4: Decay resistance of Pacific silver fir impregnated with western redcedar extractives for both leached and unleached samples.

\begin{tabular}{|c|c|c|c|c|c|c|c|}
\hline Group & Species & $\begin{array}{l}\text { Wood } \\
\text { Type }\end{array}$ & $\begin{array}{c}\text { Post } \\
\text { Treatment } \\
\text { Leaching }\end{array}$ & Fungus & $\begin{array}{l}\text { Weigh \% } \\
\text { Gain of } \\
\text { Extracts }\end{array}$ & $\begin{array}{c}\text { Moisture } \\
\text { Content } \\
(\%)\end{array}$ & $\begin{array}{c}\text { Corrected } \\
\text { Weight Loss } \\
(\%)\end{array}$ \\
\hline \multirow{3}{*}{1} & \multirow{3}{*}{ WRC } & \multirow{3}{*}{ Heartwood } & N/A & G. trabeum & N/A & 40 & $0,5(0,6)$ \\
\hline & & & N/A & R. placenta & N/A & 43 & $0,7(0,2)$ \\
\hline & & & Leached & R. placenta & N/A & 31 & $3,0(1,1)$ \\
\hline 2 & WRC & Heartwood & Leached & R. placenta & $\mathrm{N} / \mathrm{A}$ & 84 & $32,7(4,9)$ \\
\hline \multirow{3}{*}{3} & \multirow{3}{*}{ PSF } & \multirow{3}{*}{ Heartwood } & N/A & G. trabeum & $\mathrm{N} / \mathrm{A}$ & 93 & $30,8(4,8)$ \\
\hline & & & N/A & R. placenta & N/A & 96 & $53,7(4,9)$ \\
\hline & & & Leached & R. placenta & N/A & 133 & $61,1(1,4)$ \\
\hline 4 & PSF & Heartwood & Leached & R. placenta & N/A & 107 & $57,8(2,3)$ \\
\hline \multirow{3}{*}{5} & \multirow{3}{*}{ PSF } & \multirow{3}{*}{ Heartwood } & N/A & G. trabeum & $11,0(0,6)$ & 52 & $2,8(1,2)$ \\
\hline & & & N/A & R. placenta & $11,0(0,6)$ & 51 & $2,5(1,6)$ \\
\hline & & & Leached & R. placenta & $11,3(0,4)$ & 110 & $57,2(1,0)$ \\
\hline \multirow{3}{*}{6} & \multirow{3}{*}{ PSF } & \multirow{3}{*}{ Heartwood } & N/A & G. trabeum & $10,9(0,7)$ & 55 & $1,7(0,7)$ \\
\hline & & & N/A & R. placenta & $11,1(0,6)$ & 56 & $0,9(1,2)$ \\
\hline & & & Leached & R. placenta & $11,4(0,2)$ & 92 & $53,9(1,2)$ \\
\hline \multirow{3}{*}{7} & \multirow{3}{*}{ PSF } & \multirow{3}{*}{ Heartwood } & N/A & G. trabeum & $20,1(1,2)$ & 54 & $0,7(0,5)$ \\
\hline & & & N/A & R. placenta & $19,8(1,1)$ & 59 & $1,3(0,5)$ \\
\hline & & & Leached & R. placenta & $19,3(0,6)$ & 87 & $50,6(3,8)$ \\
\hline \multirow{3}{*}{8} & \multirow{3}{*}{ PSF } & \multirow{3}{*}{ Heartwood } & N/A & G. trabeum & $19,7(1,2)$ & 64 & $1,0(0,3)$ \\
\hline & & & N/A & R. placenta & $19,9(1,1)$ & 61 & $1,0(0,6)$ \\
\hline & & & Leached & R. placenta & $18,8(0,9)$ & 90 & $47,6(4,3)$ \\
\hline \multirow{2}{*}{9} & \multirow{2}{*}{ Red pine } & \multirow{2}{*}{ Sapwood } & N/A & G. trabeum & N/A & 130 & $48,3(6,9)$ \\
\hline & & & N/A & R. placenta & $\mathrm{N} / \mathrm{A}$ & 64 & $51,9(4,1)$ \\
\hline 10 & WRC & Heartwood & N/A & R. placenta & $\mathrm{N} / \mathrm{A}$ & 39 & $1,2(0,5)$ \\
\hline
\end{tabular}

*Standard deviations in parentheses.

\section{CONCLUSIONS}

Pacific silver fir impregnated with western redcedar extractives showed reduced shrinkage and hygroscopicity, but not as low as natural WRC heartwood. Impregnated extractives were susceptible to leaching. Leached samples had similar shrinkage values to untreated controls but maintained their reduced hygroscopicity. Extractive impregnation gave the wood a more cedar-like colour.

Extractive impregnated samples had increased decay resistance to G. trabeum and R. placenta and showed resistance similar to that of WRC heartwood. After leaching, extractives-impregnated PSF blocks lost their resistance to decay fungi, showing mass losses similar to untreated control sapwood samples.

\section{ACKNOWLEDGEMENTS}

The authors thank Natural Resources Canada (Canadian Forest Service) and the Province of British Columbia for their financial support and Cedarland Forest Products for donation of the western redcedar sawdust. Technical assistance from James Drummond, Ashley Hook, Stephanie Houde, Daniel Wong and Katherine Semple is gratefully acknowledged.

\section{References:}

Anderson, A.B.; Zavarin, E.; Scheffer, T.C. 1958. Nature of some decay-retardant extractive components in incense cedar heartwood (Libocedrus decurrens Torrey). Nature 181(4618):1275-1276.

American Wood Protection Association. AWPA. 2016. Laboratory method for evaluating the decay resistance of wood-based materials against pure basidiomycete cultures: soil/block test. Standard E10-16. American Wood Protection Association: Birmingham, AL. 12p. 
American Wood Protection Association. AWPA. 2016. Standard method for accelerated evaluation of preservative leaching. Standard E11-16. American Wood Protection Association: Birmingham, AL. 3p.

Clausen, C.A.; Yang, V. 2007. Protecting wood from mould, decay, and termites with multi-component biocide systems. International Biodeterioration \& Biodegradation 59(1):20-24

Daniels, C.R., Russell, J.H. 2007. Analysis of western redcedar (Thuja plicata Donn) heartwood components by HPLC as a possible screening tool for trees with enhanced natural durability. Journal of Chromatographic Science 45(5): 281-285.

Diouf, P.N.; Del Barre, N.; Perrin, D.; Gerardin, P.; Rapin, C.; Jacquot, J.P. Gelhaye, E. 2002. Influence of tropolone on Poria placenta wood degradation. Applied and Environmental Microbiology 68(9):4377-4382.

Ermeydan, M.A.; Cabane, E.; Masic, A.; Koetz, J.; Burgert, I. 2012. Flavonoid insertion into cell walls improves wood properties. ACS Applied Materials \& Interfaces 4(11):5782-5789.

Glass, S.V.; Zelinka, S.L. 2010. Moisture relations and physical properties of wood. In Wood handbook-Wood as an engineering material. General Technical Report FPL-GTR-190. Madison, WI: U.S. Department of Agriculture, Forest Service, Forest Products Laboratory. 508 p.

Gonzalez, J.S. 2004. Growth, properties and uses of western red cedar (Thuja plicata Donn ex D. Don.). Special Publication-Forintek Canada Corporation (Canada) SP-37R.

Hart, J.H. 1989. The role of wood exudates and extractives in protecting wood from decay. In Natural Products of Woody Plants. Springer: Berlin Heidelberg. pp. 861-880.

Johansson, C.I.; Saddler, J.N.; Beatson, R.P. 2000. Characterization of the polyphenolics related to the colour of western red cedar (Thuja plicata Donn) heartwood. Holzforschung 54(3):246-254.

Kai, Y.; Swan, E.P. 1990. Chemical constituents contributing to the color of western red cedar heartwood. Mokuzai Gakkaishi 36(3):218-224.

Kirker, G.T.; Blodgett, A.B.; Lebow, S.; Clausen, C.A. 2013. Transferable Durability: Enhancing decay resistance of non-durable species with extractives from durable wood species. Int Res Group Wood Protection. Document No. IRG/WP/13-10808. Stockholm, Sweden. 12p.

Li, S.; Freitag, C.M.; Morrell, J.J.; Okabe, T. 2012. Antifungal effects of hinokitiol and its sodium salt for wood protection. BioResources 7(4):5312-5318.

Macdonald, B.F.; Maclean, H. 1965. Effect of high temperature on the durability of western red cedar. Canadian Forest Industries 85(3):93.

Morris, P.I. 1995. Pacific silver fir is the more-treatable component of hem-fir from coastal British Columbia. Forest Products Journal 45(9):37-40.

Rudman, P. 1962. The causes of natural durability in t-40imber. IX. The antifungal activity of heartwood extractives in a wood substrate. Holzforschung 16(3):74-77.

Sakai, K.; Matsunaga, M.; Minato, K.; Nakatsubo, F. 1999. Effects of impregnation of simple phenolic and natural polycyclic compounds on physical properties of wood. J Wood Sci 45(3):227-232.

Shi, J.; Avramidis, S. 2018. Dried cell wall nanopore configuration of Douglas-fir, western red cedar and aspen heartwoods. Wood Sci Technol 52(4):1025-1037.

Silviera, A.G.; Santini, E.J.; Kulczyski, S.M.; Trevisan, R.; Wastowski, A.D.; Gatto, D.A. 2017. Tannic extract potential as natural wood preservative of Acacia mearnsii. An Acad Bras Ciênc 89(4):3031-3038.

Southam, C.M.; Ehrlich, J. 1943. Effects of extract of western red-cedar heartwood on certain wood-decaying fungi in culture. Phytopathology 33:517-524. 
Stirling, R.; Morris, P.I. 2006. The influence of extractives on western red cedar's equilibrium moisture content. Int Res Group Wood Protection. Document No. IRG/WP/06-40331. Stockholm Sweden. 12p.

Stirling, R.; Morris, P.I. 2016. Potential contributions of lignans to decay resistance in western red cedar. Wood Sci Technol 50(2):399-412.

Stirling, R.; Sturrock, R.N.; Baybrooks, A. 2017. Fungal decay of western redcedar wood products-a review. International Biodeterioration \& Biodegradation 125:105-115.

Taylor, A.M.; Gartner, B.L.; Morrell, J.J. 2002. Heartwood formation and natural durability-a review. Wood Fiber Sci 34(4):587-611.

Turner, P.; Conradie, D. 1995. The chemical analysis and biological evaluation of wood extractives as potential timber preservatives. Int Res Group Wood Protection. Document No. IRG/WP/95-30090. Stockholm, Sweden. 9p.

Wangaard, F.F.; Granados, L.A. 1967. The effect of extractives on water-vapor sorption by wood. Wood Sci Technol 1(4):253-277.

Yamamoto, K.; Hong, L.T. 1988. Decay resistance of extractives from chengal (Neobalanocarpus heimii). Journal of Tropical Forest Science 1(1):51-55.

Yano, H. 1994. The changes in the acoustic properties of Western Red Cedar due to methanol extraction. Holzforschung 48(6):491-495. 